Article

\title{
Effects of Owinema Bio-Preparation on Vermicomposting in Earthworm Ecological Boxes
}

\author{
Mariola Garczyńska ${ }^{1}{ }^{*}$, Grzegorz Pączka ${ }^{1}$, Agnieszka Podolak ${ }^{1}$, Anna Mazur-Pączka ${ }^{1}$, \\ Renata Szura ${ }^{1}$, Kevin R. Butt ${ }^{2} \mathbb{D}$ and Joanna Kostecka ${ }^{1}$ \\ 1 Department of the Basis of Agriculture and Waste Management, Institute of Agricultural Sciences, Land \\ Management and Environmental Protection, College of Natural Sciences, University of Rzeszow, 1a \\ Cwiklinskiej st., 35-601 Rzeszow, Poland; grzegp@ur.edu.pl (G.P.); apodolak@ur.edu.pl (A.P.); \\ anamazur@ur.edu.pl (A.M.-P.); sekzppr@ur.edu.pl (R.S.); jkosteck@ur.edu.pl (J.K.) \\ 2 Forensic and Applied Sciences, University of Central Lancashire, Preston PR 1 2HE, UK; krbutt@uclan.ac.uk \\ * Correspondence: mgar@ur.edu.pl; Tel.: +48-17-872-1649
}

Received: 28 November 2019; Accepted: 6 January 2020; Published: 8 January 2020

check for updates

\begin{abstract}
This paper describes vermicomposting of kitchen organic waste with the use of Eisenia fetida earthworms in an ecological box. To control excessively proliferated Sciaridae in the box medium, an Owinema bio-preparation, which contains larvae of the nematode Steinernema feltiae, was used. The effect of this bioinsecticide on the earthworm population during vermicomposting of organic waste was assessed. It was found that the applied bio-preparation effectively limited the population of sciarids and also had a positive effect on the development of the earthworm population (it caused a significant increase in the number and biomass of mature and immature forms and cocoons produced $(p<0.05)$ ). The Owinema preparation also had a positive effect on the rate of organic waste vermicomposting.
\end{abstract}

Keywords: vermicomposting; earthworms E. fetida; Sciaridae larvae; Owinema bio-preparation

\section{Introduction}

A consumerist lifestyle generates a great amount of waste, including organic residues. One of the ways to manage them on-site (in the place of production), is to use an "earthworm ecological box" [1]. This example of pro-environmental processing of organic wastes reduces risk for people and the environment.

"Earthworm ecological boxes" are small containers for vermiculture. These enable processing of segregated organic waste at home, at school, in hospitals, in canteens, and at other places of work. Since uncontaminated waste is obtained, it is possible to use it for the production of high-quality vermicompost. Keeping an "earthworm ecological box" is still an unconventional activity, but it gives an opportunity to organize waste management according to the principles of sustainable development. It helps to prevent negative consequences of bio-waste accumulation on landfill sites and to reduce the cost of bio-waste management, e.g., cost of transport to landfill sites.

There are many other positive aspects of using earthworms, for example, we can also neutralize a variety of segregated wastes on a larger scale, such as sewage sludge [2] or kitchen wastes [3]. Vermicomposting is a pro-environmental biotechnology [4], but in small containers it can be problematic as relatively small earthworm populations lose their dynamics of growth easily and the system can also become dominated by other organisms.

In "earthworm ecological boxes", the earthworms normally used are Eisenia fetida (Savigny, 1826); however, biodiverse representatives of the soil fauna may also be present. These can include the following organisms: Protozoa, Collembola, Enchytraeidae, Nematodes, Acarida, and Insecta. 
Excessive overcrowding of, for example, Enchytraeidae may impede the development of E. fetida populations and consequently disrupt the vermicomposting process. Enchytraeidae release substances toxic to earthworms; therefore, even if both families of Oligochaeta exist in one habitat, earthworms can starve to death despite the availability of organic wastes in the substrate [5].

Seeking methods of efficient and convenient maintenance of an "earthworm ecological box", we may encounter one more obstacle-the presence of Sciaridae larvae. Their mature forms are burdensome for the user of the "earthworm ecological box", and their larvae might compete with earthworms for organic wastes [6]. They can be eliminated using natural methods or xenobiotics [7-9].

Chemical plant protection is, on the one hand, beneficial due to rapid reduction of unwanted organisms, but on the other hand, due to a relatively low selectivity of measures, it contributes to biological imbalance in the environment. Soil organisms show various strategies of survival under chemical stress conditions [10-13]. The effect of insecticides on soil organisms is complex, and it depends on numerous abiotic factors and complex synergistic and antagonistic reactions [14]. This is the reason for the use of bioinsecticides, since they are more biodegradable, more target-specific, and characterized by lower toxicity in relation to other organisms [15-17]. Numerous authors have examined and compared the effect of natural preparations and xenobiotics on specific pests and non-target organisms (e.g., pests-larval stages of Spodoptera litura; non-target organisms-E. fetida earthworms).

Ponsankar et al. [18] showed that a natural bioinsecticide isolated from Couroupita guianensis (cannonball tree) may be a good alternative to insecticides (monotrophos and cypermethrin) in limiting the S. litura larva pests. An important fact is that it was safe for earthworms (E. fetida), confirmed by both the contact paper test and artificial soil test. Selin-Rani et al. [19] obtained similar results with the same previously described test organisms, but these authors compared the effect of quercetin isolated from Euphorbia hirta with monotrophos and cypermethrin.

An important group of natural insecticides is preparations based on selected nematode strains of the family Steinernematidae (over 61 species) and Heterorhabditae (over 14 species). These have become an alternative to many insecticides, especially in integrated crops [20]. For both of the above-mentioned groups, a significant role is played by larvae: for Steinernematidae, third-stage larvae, and for Heterorhabditae, second- and third-stage larvae. These larval stages contain symbiotic bacteria of the genus Xenorabdus (inhabiting the intestinal vesicle of nematodes) or Photorhabdus (occurring in the intestine of nematodes), which kill potential hosts. Their development takes place in the hemocoel and tissues of the host. The invasive forms of nematodes, used in bio-preparations, are not able to live outside potential hosts, e.g., Sciaridae. That is why the preparations appear to be safe for other soil fauna. Entomopathogenic nematodes weaken the host immune system by releasing proteinases which destroy pathogens, and they become an adequate environment for the development of bacteria [21,22]. The above-mentioned biological preparations containing live nematode larvae may be effective in reducing the number of Sciaridae in greenhouse crops and under laboratory conditions.

Nevertheless, the use of insecticides reducing Sciaridae (Dimilin 25WP, Nomolt 250SC, and Dar 2.5GR), even at doses safe for the environment, had an effect on the second generation (F1) of compost earthworms E. fetida, that is, cocoons produced by the earthworms $[7,8]$.

The relationships between earthworms and nematodes need further studies. They may be based on a phenomenon called phoresy, that is, transportation of one organism by another to obtain food or shelter. Phoresy may contribute to the direct effect of earthworms on the spread of nematodes in the soil environment. This phenomenon was confirmed in studies by Karakas [23]. He showed that the presence of earthworms (Aporrectodea caliginosa and Lumbricus rubellus) in the medium had a positive effect on spread of $S$. feltiae nematodes in soil, as compared with medium without earthworms.

Campos-Herrera et al. [24] also studied the phenomenon of phoresy between earthworms E. fetida (mature and young) and nematodes Steinernema felitiae from two strains (strain from ENTONEM and nematodes RIOJA) for $24 \mathrm{~h}$ and $48 \mathrm{~h}$. Compost earthworms transported both nematode strains with varied efficacy, which was in the range of $20 \%-90 \%$. Both young and mature earthworms E. fetida more 
frequently transported the strain RIOJA via the intestine (about $83 \%-92 \%$ nematodes $S$. feltiae; there were 1 to 11 nematodes per earthworm). After passing through the earthworm intestine, the nematodes became less virulent toward the larvae of Galleria mellonella. Their number was often reduced, which could be caused by earthworm digestive enzymes and microbial activity, since numerous soil microorganisms (bacteria, protozoa, algae, fungi, or nematodes) are food for annelids. Similar results were obtained by Shapiro et al. [25], who showed lower virulence of nematodes Steinernema carpocapsae towards insect larvae (G. mellonella) after isolating them from young earthworms Lumbricus terrestris and Aporrectodea trapezoides.

The aim of the work undertaken here was to determine the influence of an Owinema bio-preparation on E. fetida (rate of waste vermicomposting) and Sciaridae larvae in "earthworm ecological boxes".

\section{Materials and Methods}

\subsection{Earthworms and the Influence of an Owinema Bio-Preparation on Population Dynamics}

Compost earthworms obtained from long-term conservative breeding, deriving from germinal material, were used to start the experiment. In each of five containers (capacity of $2 \mathrm{dm}^{3}$ ), 50 earthworms (40 mature and 10 immature) were introduced and kept for 5 months (Table 1). Earthworms were maintained in plastic containers $(20 \times 15 \times 10 \mathrm{~cm})$ with soil and a designed mixture of organic waste containing residues of each of boiled pasta, bread, and potato and apple peelings ( $600 \mathrm{~mL}$ in total) mixed with $300 \mathrm{~mL}$ of cellulose (fragmented paperboard) which improves vermicomposting conditions [26].

Table 1. Experiment design.

\begin{tabular}{|c|c|c|c|}
\hline Container & Medium & Earthworm Eisenia fetida & Feeding \\
\hline 1-5 A & $2 \mathrm{dm}^{3}$ of garden soil $*$ & by 50 individuals of known & 5 times, after $600 \mathrm{~mL}$ of designed \\
\hline Control & $\begin{array}{c}2 \mathrm{dm}^{3} \text { of garden soil } \\
\text { preparation }\end{array}$ & $\begin{array}{c}\text { biomass } \\
\text { by } 50 \text { individuals of known } \\
\text { biomass }\end{array}$ & $\begin{array}{l}\text { mixture of organic waste and } \\
\text { cellulose }(2: 1)\end{array}$ \\
\hline
\end{tabular}

* Universal substrate for ornamental plants: $\mathrm{pH}$ 5.5-6.5. Composition: highmoor peat, lowmoor peat, pearlite, sand, microelements, mineral fertilizer NPK universal growing medium Kronen: $\mathrm{pH}$ in $\mathrm{H}_{2} \mathrm{O}$ 6.0-6.5; salinity 1.0-2.0 $\left(\mathrm{mg} \cdot \mathrm{dm}^{-3}\right) ; \mathrm{N} 200-450\left(\mathrm{mg} \cdot \mathrm{dm}^{-3}\right) ; \mathrm{P}_{2} \mathrm{O}_{5} 200-400,\left(\mathrm{mg} \cdot \mathrm{dm}^{-3}\right) ; \mathrm{K}_{2} \mathrm{O} 300-500\left(\mathrm{mg} \cdot \mathrm{dm}^{-3}\right)$; solid form, loose form, fraction 0-20 mm. ${ }^{* *}$ bio-preparation Owinema in a dose of $50 \mathrm{mln}$ larvae $\mathrm{m}^{-2}$ as recommended by the producer [27].

To maintain appropriate waste humidity, it was dampened every 7 days with the same volume (100 $\mathrm{mL}$ ) of tap water (pH 7.5, conductivity $486 \mu \mathrm{S} \mathrm{cm}^{-1}$, nitrates V $8.5 \mathrm{mg} \mathrm{dm}^{-3}$, nitrates III $0.01 \mathrm{mg} \mathrm{dm}^{-3}$, $\mathrm{Mg} 14.2 \mathrm{mg} \mathrm{dm}^{-3}$, water hardness $231 \mathrm{mg} \mathrm{CaCO}_{3} \mathrm{dm}^{-3}$ ).

The dynamics of the earthworm populations during vermicomposting of kitchen waste was assessed five times on a regular monthly basis, by a hand sorting method [28]. While checking the state of the earthworm population, the number of Diptera larvae in the ecological box substrate was also assessed (by taking three samples of $30 \mathrm{~mL}$ each and analyzing them by way of a wet funnel method) [29]. The studies were conducted under controlled laboratory conditions $\left(20 \pm 5^{\circ} \mathrm{C} ; 24 \mathrm{~L}\right.$ constant humidity about $70 \%[30,31]$. The experiment was replicated five times.

\subsection{Kitchen Wastes and the Rate of Vermicomposting}

The above-mentioned kitchen waste was placed in a large-mesh nylon bag, isolating it from the old medium but allowing free access of earthworms to the interior.

The rate of waste processing into vermicompost was determined regularly (during inspection of the earthworm population in the control and treatment containers) by multiple comparison of the volume of the unprocessed wastes. Regularly (every 3 weeks), the volume of the processed and unprocessed leftovers was measured with the use of the formula presented below. 
The results obtained were compared with the volume of the leftovers processed into vermicompost according to the following formula:

$$
a_{t}=900-b_{t}
$$

where $a_{t}$ is the volume of processed leftovers in subsequent examinations and $b_{t}$ is the volume of subsequently determined leftovers (not processed by earthworms).

After determining the volume of the processed and unprocessed leftovers, they were re-introduced into the box, adding another portion of food, in the same amount for the two types of boxes.

In the vermicomposts produced, the $\mathrm{pH}$ in water was determined using a potentiometric method and the concentration of salt by a conductometric method (in $\mathrm{g} \mathrm{NaCl} \mathrm{dm}^{-3}$ ). The content of total nitrogen was tested by Kjeldahl methodology, and the phosphorus content was tested by using the vanadic-molybdenic method. The levels of potassium, calcium, and magnesium $\left(\mathrm{mg} \mathrm{dm}^{-3}\right)$ were analyzed using an ASA method [32].

\subsection{The Influence of Owinema Bio-Preparation on Sciaridae Larvae}

Before the experiment, the number of flies in the lab room was increased by multiplying it for 4 weeks on mushroom mycelium infected with larvae of Sciaridae; at the beginning of the experiment, the ecological boxes $(n=10)$ contained $5480.0 \pm 1778.5$ larvae of Sciaridae per liter of medium.

An Owinema bio-preparation (Owiplant) was introduced at a dose recommended by the producer (in concentration $50 \mathrm{mln}$ of larvae $\mathrm{m}^{-2}$ ). The preparation was introduced to five of the boxes. The remaining five boxes were used as a control (Table 1 ).

The effect of an Owinema bio-preparation is based on invasive larvae of nematodes Steinernema feltiae which penetrate the vascular system of insects through a natural opening of the body or through the cuticle (Figure 1). The host dies and the nematodes form the first generation and reproduce themselves. The invasive larvae from the host enter the environment and seek the next hosts [15].

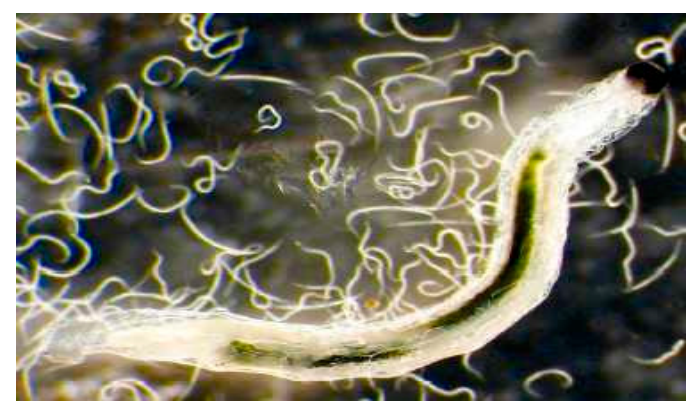

Figure 1. Sciaridae larva attacked by nematodes.

\subsection{Statistical Analysis}

To test for significant differences between the data related to parameters of populations, data were subjected to a two-way ANOVA with the LSD test (post-hoc). In case of heterogenic variance, a Kruskall-Wallis with post-hoc test (multiple comparisons of mean ranks) was used. For data connected with the parameters of vermicomposts, a $t$-test or $t$-test with an independent estimation of variance was applied (heterogenic variance). A Shapiro-Wilk test was used beforehand to check for normality in the groups and a Brown-Forsythe test to check homogeneity of variance. Where necessary, Spearman rank correlation was applied [33].

The results are expressed as means $\pm \mathrm{SD}$. The level of significance is $\alpha=0.05$. Statistical analyses were performed by means of STATISTICA v.10 (StatSoft). 


\section{Results}

\subsection{The Influence of Owinema Preparation on Earthworms}

\subsubsection{Number of Earthworms}

The Owinema bio-preparation had a positive effect on the population size of E. fetida compared to the control groups $(F=92.193, p<0.001)$. The mean number of earthworms was significantly higher for groups treated with Owinema bio-preparation (Table 2).

Table 2. Mean number of E. fetida individuals (ind·container ${ }^{-1} \pm \mathrm{SD}$ ) in experimental "ecological boxes" depending on the presence of an Owinema bio-preparation $\left(50 \mathrm{mln}\right.$ larvae $\left.\mathrm{m}^{-2}\right)$ during a 5 month experiment.

\begin{tabular}{ccccccc}
\hline Time & $\begin{array}{c}\text { Start of the } \\
\text { Experiment }\end{array}$ & 1st Month & 2nd Month & 3rd Month & 4th Month & 5th Month \\
\hline Control & $50.0 \pm 0.0^{\mathrm{a}}$ & $239.8 \pm 24.8^{\mathrm{a}}$ & $303.6 \pm 25.6^{\mathrm{a}}$ & $461.0 \pm 59.0^{\mathrm{a}}$ & $421.8 \pm 45.7^{\mathrm{a}}$ & $123.2 \pm 55.8^{\mathrm{a}}$ \\
\hline Owinema & $50.0 \pm 0.0^{\mathrm{a}}$ & $302.4 \pm 19.5^{\mathrm{a}}$ & $\begin{array}{c}372.0 \pm 51.6 \\
\mathrm{~b}\end{array}$ & $\begin{array}{c}552.4 \pm 113.1 \\
\mathrm{~b}\end{array}$ & $\begin{array}{c}732.0 \pm 34.6 \\
\mathrm{~b}\end{array}$ & $\begin{array}{c}640.6 \pm 59.2 \\
\mathrm{~b}\end{array}$ \\
\hline \multicolumn{7}{c}{ a,b-significant differences. }
\end{tabular}

In the boxes containing Owinema, many more reproducing (mature) individuals were found in the third $(H=3.938, p<0.05)$ and fourth $(H=6.818, p<0.01)$ month of the experiment (Figure 2A). Similarly, for immature earthworms, there was also a positive Owinema effect on the mean number of earthworms observed in most cases $(F=81.460, p<0.001)$ (Figure 2B).

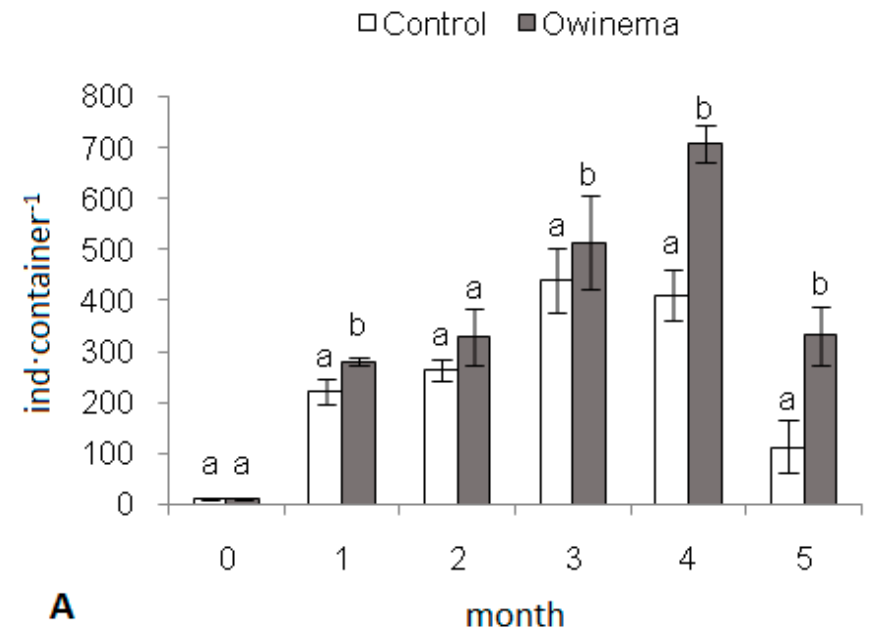

Figure 2. Cont. 


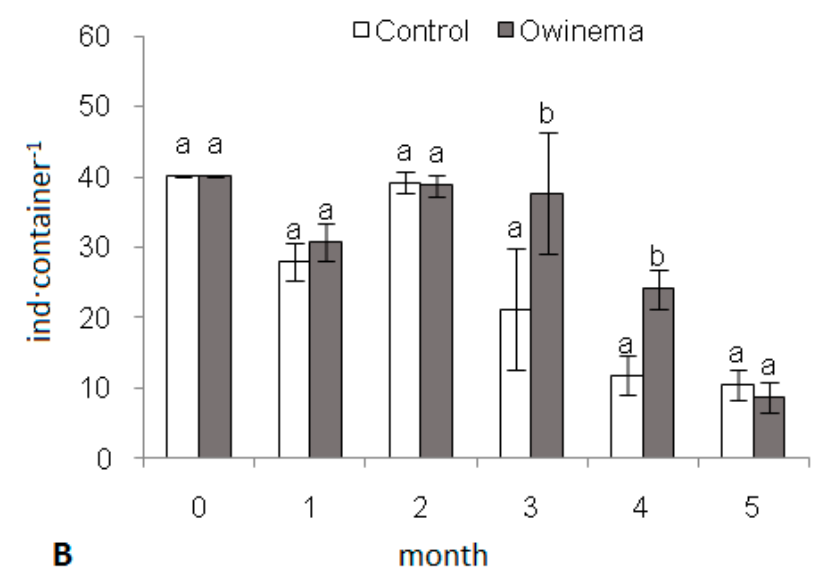

Figure 2. Mean number of E. fetida individuals (ind.container ${ }^{-1} \pm \mathrm{SD}$ ) in experimental ecological boxes depending on the presence of an Owinema bio-preparation ( $50 \mathrm{mln}$ larvae $\left.\mathrm{m}^{-2}\right)$ during a $5 \mathrm{month}$ experiment: (A) mature, (B) immature ( $a, b$ indicate significant differences between two means).

\subsubsection{Body Mass}

The biomass of the earthworms in the experimental boxes was higher compared to that in the control group $(F=168.918, p<0.001)$. At the end of the experiment the mean biomass of the group treated with Owinema was more than twice that of the E. fetida population in the control containers $(F=36.149, p<0.001)($ Table 3$)$.

Table 3. Mean biomass of E. fetida (g.container ${ }^{-1} \pm \mathrm{SD}$ ) in experimental ecological boxes depending on the presence of Steinernema feltiae $\left(50 \mathrm{mln}\right.$ larvae $\left.\mathrm{m}^{-2}\right)$ during a 5 month experiment.

\begin{tabular}{ccccccc}
\hline Time & $\begin{array}{c}\text { Start of the } \\
\text { Experiment }\end{array}$ & 1st Month & 2nd Month & 3rd Month & 4th Month & 5th Month \\
\hline Control & $20.14 \pm 0.19^{\mathrm{a}}$ & $25.47 \pm 3.58^{\mathrm{a}}$ & $26.73 \pm 7.96^{\mathrm{a}}$ & $20.31 \pm 2.74^{\mathrm{a}}$ & $36.62 \pm 4.08^{\mathrm{a}}$ & $14.75 \pm 6.75^{\mathrm{a}}$ \\
\hline Owinema & $20.09 \pm 0.10^{\mathrm{a}}$ & $31.74 \pm 5.73^{\mathrm{b}}$ & $24.66 \pm 1.52^{\mathrm{a}}$ & $44.64 \pm 6.62^{\mathrm{b}}$ & $82.57 \pm 5.26^{\mathrm{b}}$ & $37.75 \pm 5.35^{\mathrm{b}}$ \\
\hline \multicolumn{7}{c}{${ }^{\mathrm{a}, \mathrm{b}}$ - significant differences. }
\end{tabular}

Analyzing earthworms divided into two age classes, positive effects of the Owinema bio-preparation were found on the mean biomass of mature $(F=4.150, p<0.05)$ (Figure 3A) and immature individuals $(F=165.523, p<0.001)$ (Figure 3B).

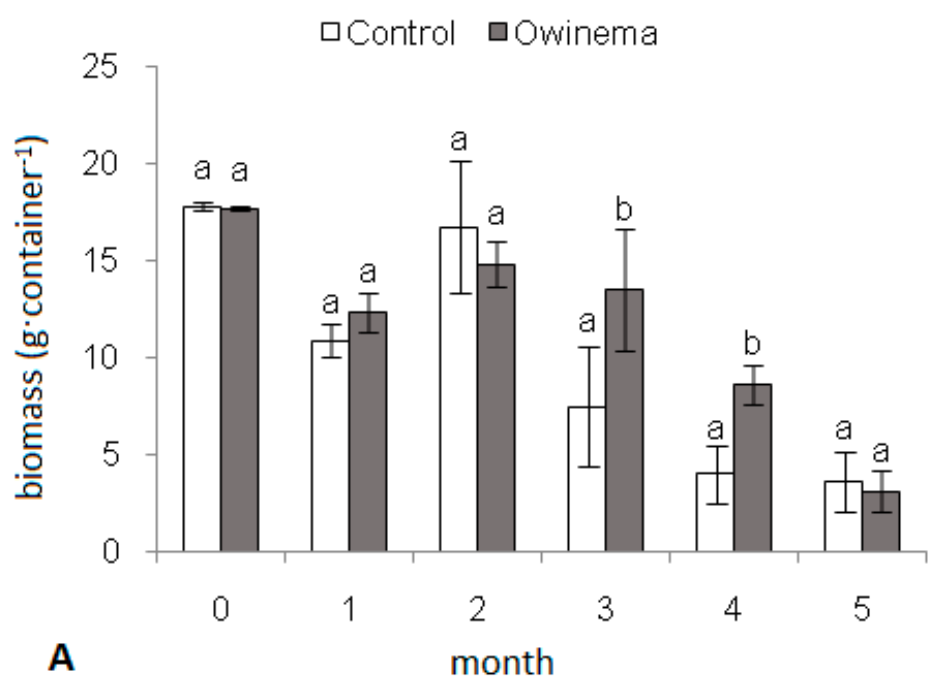

Figure 3. Cont. 


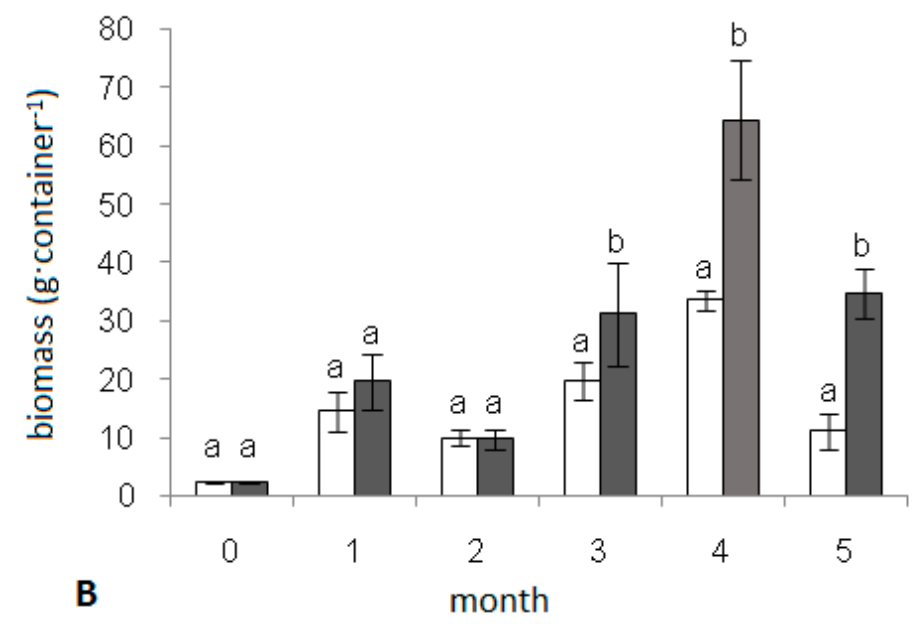

Figure 3. Mean biomass of E. fetida (g. container $\left.^{-1} \pm \mathrm{SD}\right)$ in experimental ecological boxes depending on the presence of an Owinema bio-preparation ( $50 \mathrm{mln}$ larvae $\mathrm{m}^{-2}$ ) during a 5 month experiment: (A) mature, (B) immature ( $a, b$ indicate significant differences between two means).

The presence of Owinema bio-preparation also differentiated the number and biomass of the cocoons laid in the substrate.

Although the mean number of cocoons observed in both groups was similar at the end of the experiment (Figure 4), there was a positive effect of the Owinema bio-preparation on the mean number of cocoons over the five months of observation $(F=21.496, p<0.001)$.

\section{口Control aOwinema}

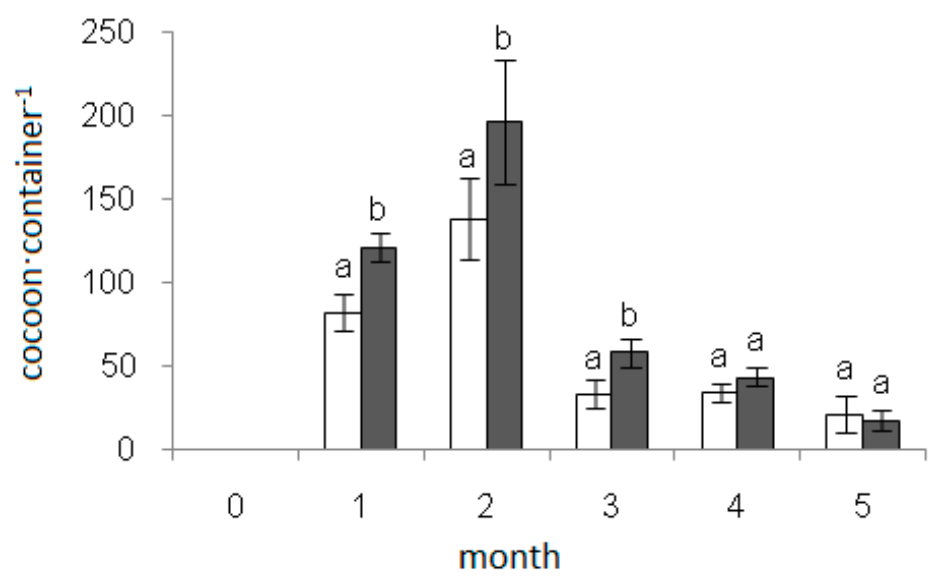

Figure 4. Mean number of E. fetida cocoons (cocoons.container ${ }^{-1} \pm \mathrm{SD}$ ) in experimental ecological boxes depending on the presence of an Owinema bio-preparation $\left(50 \mathrm{mln}\right.$ larvae $\left.\mathrm{m}^{-2}\right)$ during a 5 month experiment ( $\mathrm{a}, \mathrm{b}$ indicate significant differences between two means).

Analyzing the mean biomass of E. fetida cocoons, significantly higher values were observed in the group treated with Owinema in the first $(H=6.859, p<0.05)$ and third $(H=4.811, p<0.05)$ months of the experiment (Figure 5). 


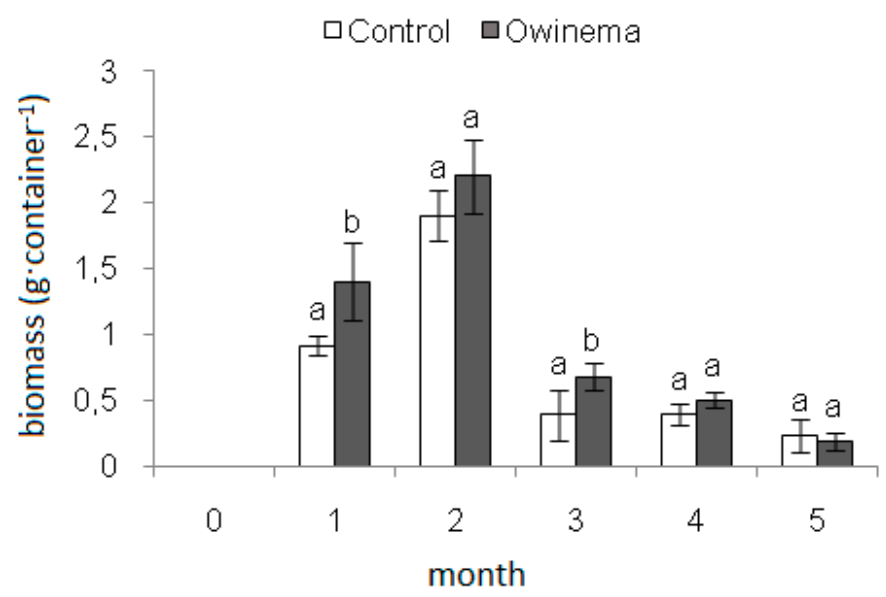

Figure 5. Mean biomass of E. fetida cocoons (g.container ${ }^{-1} \pm \mathrm{SD}$ ) in experimental ecological boxes depending on the presence of Owinema bio-preparation (50 mln larvae $\mathrm{m}^{-2}$ ) during a $5 \mathrm{month}$ experiment ( $a, b$ indicate significant differences between two means).

Moreover, a considerable moderate correlation was identified between the number of mature earthworms and cocoons in the control $\left(r_{s}=0.661, p<0.05\right)$ and in the experimental group $\left(r_{s}=0.491\right.$, $p<0.05$ ) (Figure 6A,B).

A

Cocoon number $=-6.041+3.2134^{*}$ mature number Correlation: $\mathrm{r}=0.80134$
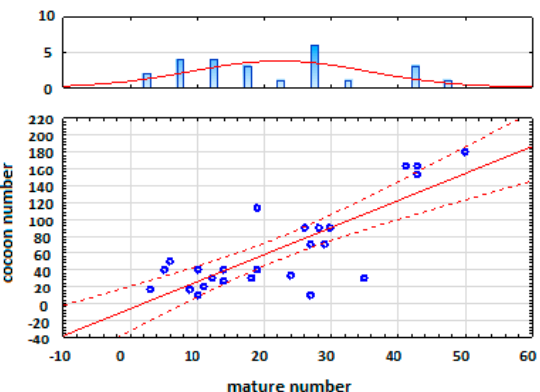

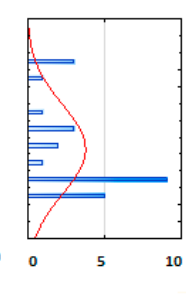

B
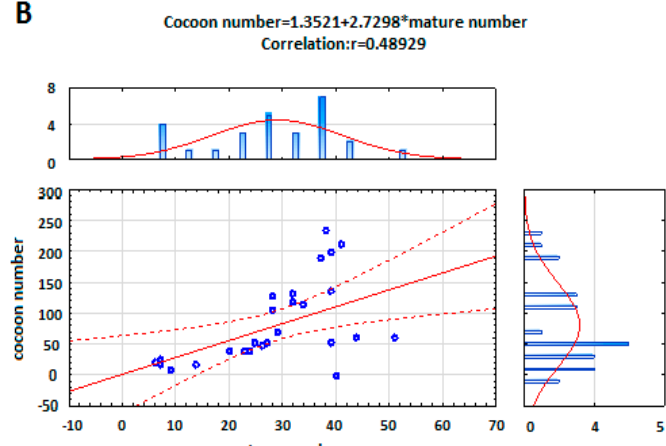

Figure 6. Correlation between the number of mature earthworms and number of produced cocoons $\left(X \pm 0.95\right.$ confidence interval): (A) Control, (B) Owinema bio-preparation (50 mln larvae $\left.\mathrm{m}^{-2}\right)$.

During each month of the experiment, the numbers of cocoons produced by an individual mature earthworm were similar $(F=1.397, p=0.242)$. These values were unaffected by exposure to Owinema $(F=0.398, p=0.531)($ Table 4$)$.

Table 4. Mean cocoon production (cocoons.mature ind ${ }^{-1} \pm \mathrm{SD}$ ) of mature Eisenia fetida individuals in experimental ecological boxes depending on the presence of Owinema bio-preparation ( $50 \mathrm{mln}$ larvae $\mathrm{m}^{-2}$ ) during a 5 month experiment.

\begin{tabular}{cccccccc}
\hline Time & $\begin{array}{c}\text { Start of the } \\
\text { Experiment }\end{array}$ & 1st Month & 2nd Month & 3rd Month & 4th Month & 5th Month & Mean \\
\hline Control & $0.0 \pm 0.0^{\mathrm{a}}$ & $2.9 \pm 0.4^{\mathrm{a}}$ & $4.2 \pm 1.0^{\mathrm{a}}$ & $2.8 \pm 3.2^{\mathrm{a}}$ & $3.6 \pm 2.6^{\mathrm{a}}$ & $2.5 \pm .19^{\mathrm{a}}$ & $2.7 \pm 1.5^{\mathrm{a}}$ \\
\hline Owinema & $0.0 \pm 0.0^{\mathrm{a}}$ & $3.9 \pm 0.4^{\mathrm{a}}$ & $5.0 \pm 1.0^{\mathrm{a}}$ & $1.7 \pm 0.5^{\mathrm{a}}$ & $1.8 \pm .0 .2^{\mathrm{a}}$ & $2.3 \pm 1.2^{\mathrm{a}}$ & $2.4 \pm 1.8^{\mathrm{a}}$ \\
\hline \multicolumn{8}{c}{$\mathrm{a}$ a - no significant differences. }
\end{tabular}

\subsection{Kitchen Wastes and the Rate of Vermicomposting}

The bio-preparation had a positive influence on the course of the vermicomposting rate. In the containers with this bio-preparation, the earthworms processed $29 \%$ more waste than those in the 
control. The daily vermicomposting rate was significantly higher in the containers with bio-preparation $\left(24 \pm 3.09 \mathrm{ml} \cdot \mathrm{day}^{-1}\right)$ compared to the control group $(p<0.001)$.

The characteristics of the vermicompost obtained are given in Table 5. Comparisons of its qualities proved to be insignificant.

Table 5. Characteristics of the vermicompost obtained from organic waste (components marked in fresh mass, at vermicompost humidity of $70 \%$ ).

\begin{tabular}{|c|c|c|c|c|c|c|c|}
\hline \multirow{2}{*}{ Characteristics } & \multirow{2}{*}{$\mathrm{pH}$ in $\mathrm{H}_{2} \mathrm{O}$} & \multirow{2}{*}{ Salinity $\mathrm{NaCl}\left[\mathrm{g} \mathrm{dm}^{-3}\right]$} & \multicolumn{5}{|c|}{ Components (mg.dm ${ }^{-3}$ of Fresh Mass) } \\
\hline & & & $\mathrm{N}-\mathrm{NO}_{3}$ & $\mathbf{P}$ & K & $\mathrm{Ca}$ & $\mathrm{Mg}$ \\
\hline Control & $6.06 \pm 0.21^{a}$ & $5.39 \pm 1.01^{a}$ & $880 \pm 89^{a}$ & $345 \pm 66^{a}$ & $1415 \pm 198^{a}$ & $2124 \pm 351^{a}$ & $279 \pm 67^{a}$ \\
\hline $\begin{array}{l}\text { Vermicomposting } \\
\text { with Owinema }\end{array}$ & $6.13 \pm 0.44^{\mathrm{a}}$ & $4.80 \pm 1.36^{\mathrm{a}}$ & $879 \pm 131^{a}$ & $324 \pm 60^{\mathrm{a}}$ & $1394 \pm 283^{a}$ & $1951 \pm 286^{a}$ & $284 \pm 62^{a}$ \\
\hline
\end{tabular}

\subsection{The Influence of Owinema Bio-Preparation on Sciaridae Larvae}

Bio-preparation application resulted in a significant decrease in the number of Sciaridae larvae observed after the first month of the experiment $(H=15.001, p<0.001)$. The number of larvae gradually dropped in both groups; however, significantly fewer Diptera larvae were recovered in the groups treated with Owinema (Figure 7A).

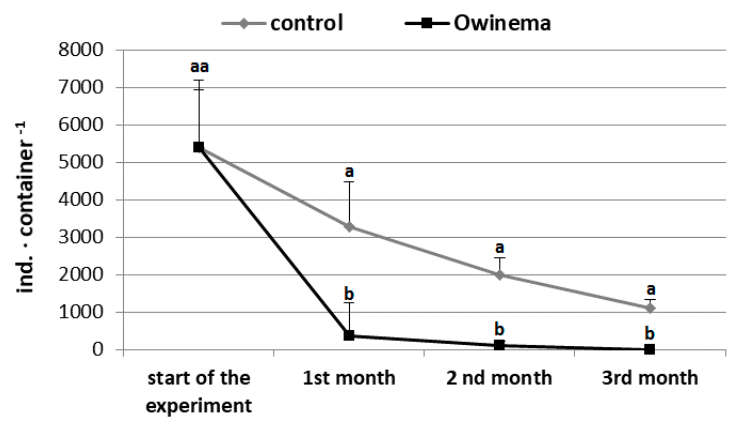

(A)

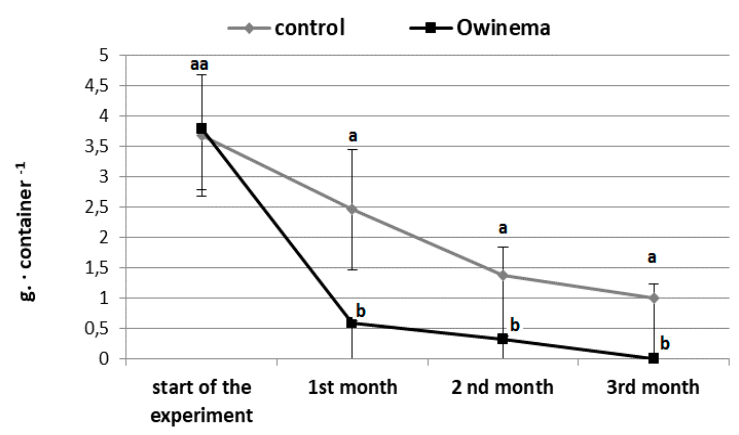

(B)

Figure 7. (A) Mean number of Diptera larvae (ind-liter ${ }^{-1} \pm \mathrm{SD}$ ) in experimental ecological boxes depending on the presence of Owinema bio-preparation (50 mln larvae $\mathrm{m}^{-2}$ ). (B) Mean biomass of Diptera larvae $\left(\mathrm{g} \cdot \mathrm{liter}^{-1} \pm \mathrm{SD}\right)$ in experimental ecological boxes depending on the presence of Owinema bio-preparation (50 mln larvae $\mathrm{m}^{-2}$ ). a, b indicate significant differences.

During the dynamic process of reducing Sciaridae larvae, the Owinema bio-preparation also had a significant effect in reducing the total biomass of the larvae (Figure 7B).

\section{Discussion}

In the present studies it was shown that an Owinema bioinsecticide stimulated development of the study population of earthworms E. fetida (Figures 8 and 9). Contact with Owinema resulted in an increase in the number and biomass of whole populations, in addition to those of reproductive and immature individuals. In the control and Owinema media, a positive correlation with a moderate coefficient (0.40-0.69) was observed regarding the number of mature earthworms and cocoons produced by them, which supports the studies of Meissner [34]. 


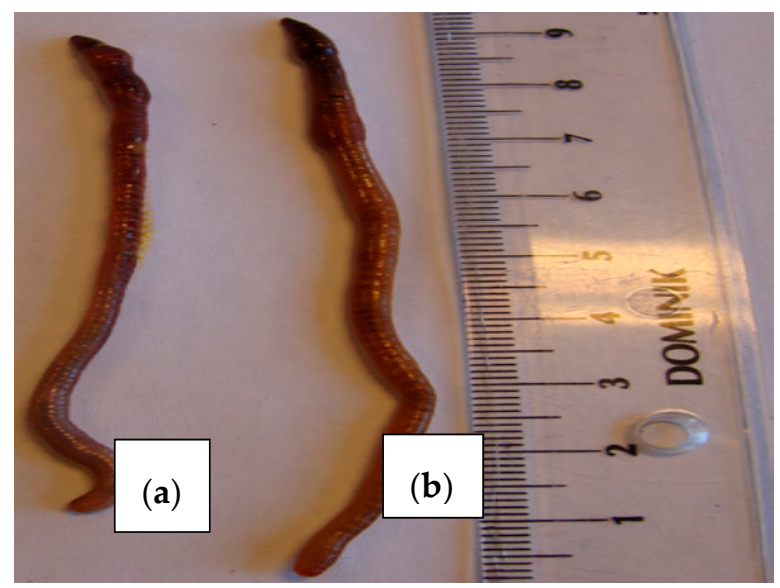

Figure 8. Mature E. fetida individuals used in the experiment: (a) control, (b) Owinema.

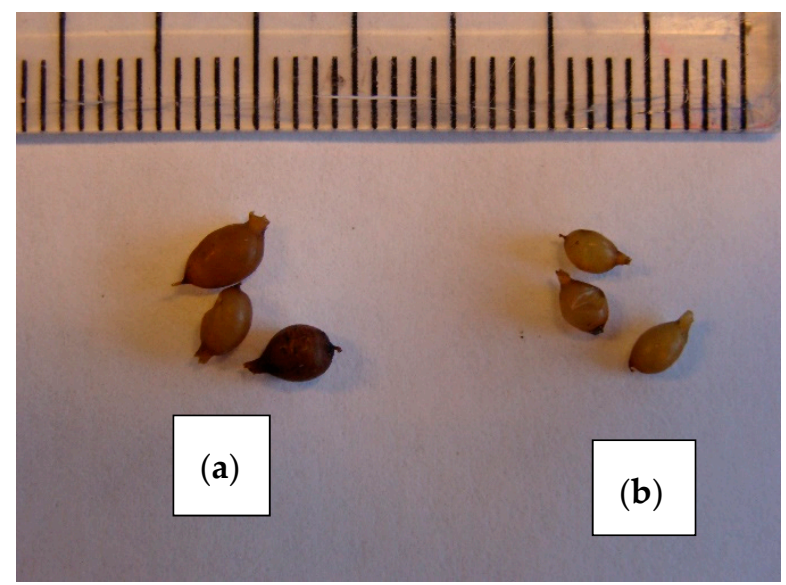

Figure 9. Cocoons produced by E. fetida: (a) Owinema, (b) control.

Under laboratory conditions or during vermicomposting of organic waste with low-scale, on-site use of compost earthworms, excessive proliferation of Sciaridae may occur, which results from the large accumulation of organic matter and relatively high humidity in the ecological boxes. At the beginning of the experiment, the density of Sciaridae larvae was $5400.0 \pm 1778.5$ for the control and $5400.0 \pm 1524.2$ for Owinema. To control the larvae, a natural Owinema preparation based on S. feltiae nematodes was used. The preparation quickly and effectively reduced the population of sciarids and also reduced competition for food in the form of organic waste between earthworms E. fetida and sciarids. Therefore, rapid and effective reduction of the Sciaridae population by the bio-preparation also had a positive effect on the daily rate of vermicomposting $(p<0.001)$.

Previously, in studies by Garczyńska and Kostecka [9], control of the Sciaridae population in ecological boxes was achieved using an alliophilic preparation based on garlic (Allium sativum) $(2 \%$ garlic extract). The preparation effectively reduced the Sciaridae population. It did not affect mature earthworms (control $46 \pm 3.6$; container with the preparation $46 \pm 3.5$ individuals) $(p>0.05)$, but contrary to the Owinema bio-preparation, it had a negative influence on the number $(p<0.01)$, biomass $(p<0.001)$, and mean mass of immature individuals $(p<0.00001)$, as well as the mean biomass of cocoons.

Dominguez et al. [35] studied the effect of earthworms Eisenia andrei on a population of nematodes and microbiological activity during vermicomposting of bovine manure and waste sludge for a period of 16 weeks. The number of bacterial-feeding nematodes was reduced by over $50 \%$ in the containers with compost earthworms for both types of processed waste. 
Annelids may be paratenic, i.e., an additional host for nematodes (e.g., for Syngamus trachea) or finally the sole host $[24,25,36]$.

The studies presented confirm the purpose and efficacy of the process of on-site vermicomposting. The vermicomposts obtained had a fine structure, with no unprocessed leftovers. Vermicomposting conducted under laboratory conditions was effective and the produce was odorless. The vermicomposts did not significantly differ in $\mathrm{pH}$ and salt concentration (although the $\mathrm{NaCl}$ concentration in $\mathrm{g} \cdot \mathrm{dm}^{-3}$ exceeded the tolerance threshold for plants of $3 \mathrm{~g} \mathrm{dm}^{-3}$ ). The presence of Owinema in the medium did not affect the vermicompost composition. Also, the vermicomposts did not differ in their contents of plant nutrients (nitrate nitrogen, assimilable phosphorus, potassium, calcium, and magnesium).

The contents of all examined nutrients exceeded the optimal level for plants, which, in combination with high salinity of the vermicomposts obtained, indicated a need for dilution before use.

The use of bio-preparations (including Owinema) brings several benefits. Bioinsecticides are safe for humans, animals, and the environment, and most of all, they have no negative impact on non-target organisms, shown in the present study with regard to compost earthworms E. fetida.

\section{Conclusions}

An Owinema preparation effectively reduced the number and biomass of Scaridae larvae. The high efficacy of Owinema in reducing the occurrence of sciarids in medium with leftovers reduced the competition for food between earthworms and sciarids, which resulted in a higher availability of food for E. fetida. This had a positive effect on a daily rate of vermicomposting of organic waste in containers with insecticide $(p<0.001)$.

Owinema had a positive effect on the numbers of the entire E. fetida population ( $F=92.193$, $p<0.001)$ and mature (in the third $(H=3.938, p<0.05)$ and fourth months $(H=6.818, p<0.01)$ after application of the bio-preparation) and immature individuals $(F=81.460, p<0.001)$. As compared to the control, the presence of Owinema preparation caused a significant increase of biomass in the whole population (at the end of the experiment, the biomass was doubled in comparison with control, $F=36.149, p<0.001)$, of mature individuals $(F=4.150, p<0.05)$, and of immature individuals $(F=165.523, p<0.001)$. The bio-preparation had a positive effect on reproduction by E. fetida. In the treatment with the bio-preparation, there were more cocoons $(F=21.496, p<0.001)$ and they had a higher biomass (in the first month after application, $H=6.859, p<0.05$; in the second and third months, $H=4.811, p<0.05$ ). The preparation did not affect the number of cocoons produced by $E$. fetida $(p>0.05)$. It may be possible to scale up these laboratory findings for industrial use, where large-scale processing of organic wastes is required and Scaridae larvae are a problem. However, there may be limitations on the transfer of laboratory tests under controlled conditions (e.g., temperature, humidity) to an industrial scale characterized by greater variability of abiotic factors.

Author Contributions: Conceptualization, M.G.; Data curation, A.M.-P., G.P. and A.P.; Investigation, M.G., A.M.-P., G.P., A.P., R.S., K.R.B., J.K.; Methodology, M.G.; Writing—original Draft, M.G.; Writing-review and editing, M.G., K.R.B. and J.K. All authors have read and agreed to the published version of the manuscript.

Funding: The project is financed under the program of the Minister of Science and Higher Education under the name "Regional Initiative of Excellence" in the years 2019-2022, project number 026/RID/2018/19 funding amount PLN 9542500.00 .

Conflicts of Interest: The authors declare no conflict of interest.

\section{References}

1. Kostecka, J.; Garczyńska, M.; Pączka, G.; Mroczek, J. Modelling the Processes of Vermicomposting in an Ecological Box-Recognized Critical Points. In Contemporary Problems of Management and Environmental Protection; Skibniewska, K.A., Ed.; Some Aspects of Environmental Impact of Waste Dumps: Olsztyn, Poland, 2011; pp. 143-156.

2. Suthar, S. Pilot-scale vermireactors for sewage sludge stabilization and metal remediation process: Comparison with small-scale vermireactors. Ecol. Eng. 2010, 36, 703-712. [CrossRef] 
3. Kostecka, J.; Pączka, G.; Garczyńska, M.; Podolak-Machowska, A.; Dunin-Mugler, C.; Szura, R. Some remarks on utilization of kitchen organic waste. Inżynieria I Ochrona Środowiska 2014, 17, 21-30.

4. Selden, P.; DuPonte, M.; Sipes, B.; Dinges, K.; Vasudevan, P. Small-scale vermicomposting. Cooperative Extension Service. Home Gard. 2005, 45, 1-4.

5. Kostecka, J.; Garczyńska, M.; Pączka, G.; Podolak, A.; Mazur-Pączka, A. Education for circular economy-Earthworm ecological boxes. Environ. Educ. Res. 2020. in review.

6. Garczyńska, M.; Kostecka, J. Dynamika muchówek ziemiórkowatych (Sciaridae) na odpadach organicznych w skrzynce ekologicznej w laboratorium. Zesz. Nauk. Poł.-Wsch. Oddziału PTIE I PTG W Rzeszowie 2014, 17, 31-36.

7. Garczyńska, M.; Kostecka, J. Influence of nomolt 150sc insecticide, used against diptera in ecological boxes, on characteristics of Eisenia fetida (sav.) earthworms. Inżynieria Ekol. 2011, 27, 13-18.

8. Garczyńska, M.; Kostecka, J. Influence of Dimilin 25 WP on characteristics of earthworm Eisenia fetida Sav, vermicomposting organic waste. Ecol. Chem. Eng. A 2011, 18, 1557-1563.

9. Garczyńska, M.; Kostecka, J. Reducing dipterian larvae Turing vermicomposting of household organic waste in ecological boxes. Soil Sci. Annu. 2012, LXIII, 18-21. Available online: http://versitaopen.com/ssa (accessed on 14 December 2019).

10. Monroy, F.; Aira, M.; Dominguez, J.; Velando, A. Seasonal population dynamics of Eisenia fetida (Savigny, 1826) (Oligochaeta, Lumbricidae) in the field. Popul. Biol. 2006, 329, 912-915. [CrossRef]

11. Aira, M.; Dominguez, J.; Monroy, F.; Velando, A. Stress promotes changes in resource allocation to growth and reproduction in a simultaneous hermaphrodite with indeterminate growth. Biol. J. Linn. Soc. 2007, 91, 593-600. [CrossRef]

12. Katagi, T.; Ose, K. Toxicity, bioaccumulation and metabolism of pesticides in the earthworm. J. Pestic. Sci. 2015, 40, 69-81. [CrossRef]

13. Pino, M.R.; Val, J.; Mainar, A.M.; Zuriaga, E.; Espanol, C.; Langa, E. Acute toxicological effects on the earthworm Eisenia fetida of 18 common pharmaceuticals in artificial soil. Sci. Total Environ. 2015, 518, 225-237. [CrossRef] [PubMed]

14. Velki, M.; Ecimović, S. Changes in exposure temperature lead to changes: A preliminary study. Environ. Toxicol. Pharmacol. 2015, 40, 774-784. [CrossRef] [PubMed]

15. Rumbos, I.C.H.; Athanassiou, C.G. The use of entomopathogenic nematodes in the control of stored-product insects. J. Pest Sci. 2017, 90, 39-49. [CrossRef]

16. Bruselman, E.; Beck, B.; Pollet, S.; Temmerman, F.; Spanoghe, P.; Moens, M.; Nuyttens, D. Effect of the spray application technique on the deposition of entomopathogeic nematodes in vegatables. Pest Manag. Sci. 2011, 68, 444-453. [CrossRef]

17. Mahenswaran, R.; Ignacimuthu, S. Bioefficiacy of essential oil from Polygonum hydropiper L. against mosquitoes, Anopheles stephensi and Culex quinquefasciatus. Ecotoxicol. Environ. Saf. 2013, 97, $26-31$. [CrossRef]

18. Ponskar, A.; Vasantha-Srinivasan, P.; Senthil-Nathan, S.; Thanigaivel, A.; Edwin, E.-S.; Selin-Rani, S.; Kalaivani, K.; Hunter, W.B.; Alessandro, R.T.; Abdel-Megeed, A.; et al. Target and non-target toxicity of botanical insecticide derived from Couroupita guianensis L. flower against generalist herbivore, Spodoptera litura Fab. And an earthworm, Eisenia foetida Savigny. Ecotoxicol. Environ. Saf. 2016, 133, 260-270. [CrossRef]

19. Selin-Rani, S.; Senthil-Nathan, S.; Thanigaivel, A.; Vasantha-Srinivasan, P.; Edwin, E.-S.; Ponskar, A.; Lija-Escaline, J.; Kalaivani, K.; Abdel-Megeed, A.; Hunter, W.B.; et al. Toxicity and physiological effect of quercetin on generalist herbivore, Spodoptera litura Fab. and a non-target earthworm Eisenia fetida Savigny. Chemosphere 2016, 165, 257-267. [CrossRef]

20. Atwa, A.A. Entomopathogenic nematodes as pesticides. In Basic and Applied Aspects of Biopesticides; Sahay, K., Ed.; Springer: Berlin/Heidelberg, Germany, 2014.

21. Davies, K.G.; Gouge, D.H. Identification of the entomopathogenic nematode bacterial symbiont Xenorhabdus species. Nematologica 1998, 44, 478.

22. Kucharska, K.; Kucharski, D.; Zajdel, B. Bacteria Xenorhabdus and Photorhabdus, entomopathogenic nematodes and insects-Their role in the complex symbiont-parasite-host relationship. Postępy Mikrobiologii 2015, 54, 154-164. Available online: http://www.pm.microbiology.pl (accessed on 11 December 2019). 
23. Karkas, M. The effect of earthworm on vertical dispersal of entomopathogenic nematode, Steinernema feltiae (Rhabditida: Steinernematidae). DUFED 2015, 4, 83-86.

24. Campos-Herrera, R.; Trigo, D.; Gutierrez, C. Phoresy of the entomopathogenic nematode Steinernema feltiae by the earthworm Eisenia fetida. J. Invertebr. Pathol. 2006, 92, 50-54. [CrossRef] [PubMed]

25. Shapiro-Ilan, D.I.; Brown, I. Earthworm as phoretic hosts for Steinernema carpocapsae and Beauveria bassiana: Implications for enhaced biological control. Biol. Control 2013, 66, 41-48. [CrossRef]

26. Kostecka, J. Investigation into vermicomposting of organic wastes. Sci. Pap. Agr. Univ. Crac. 2000, $268,1-88$.

27. Owiplant. Available online: https://owinska.cylex.pl/firmy/owiplant--sp--Z-o-o--10348244.html (accessed on 14 December 2019).

28. Pelosi, C.; Bertrand, M.; Capowiez, Y.; Boizard, H.; Roger-Estrade, J. Earthworm collection from agricultural fields: Comparisons of selected expellants in presence/absence of hand-sorting. Eur. J. Soil Biol. 2009, 45, 176-183. [CrossRef]

29. Didden, W.; Born, H.; Domm, H.; Graefe, U.; Heck, M.; Kühle, J.; Mellin, A.; Römbke, J. The relative efficiency of wet funnel techniques for the extraction of Enchytraeidae. Pedobiologia 1995, 39, 52-57.

30. ISO Soil Quality. Effects of Pollutants on Earthworms (Eisenia fetida). Part. 1: Determination of Acute Toxicity Using Artificial Soil Substrate; No 11268-1; ISO: Geneva, Switzerland, 1993.

31. ISO Soil Quality. Effect of Pollutants on Earthworms (Eisenia Fetida). Part. 2: Determination of Effects on Reproduction; No 11268-2; ISO: Geneva, Switzerland, 1998.

32. MAFF. The Analysis of Agricultural Materials, 2nd ed.; A manual of the analytical methods used by the agricultural Development and Advisory Service (ADAS); HMSO: London, UK, 1981.

33. Stanisz, A. Przystępny Kurs Statystyki Z Zastosowaniem Statistica Pl Na Przykładach Z Medycyny; StatSoft Polska Sp. Z o. o.: Kraków, Poland, 2006; p. 532.

34. Meissner, W. Metody Statystyczne W Biologii; Wydawnictwo Uniwersytetu Gdańskiego: Gdańsk, Poland, 2014; p. 158.

35. Dominguez, J.; Parmelee, R.W.; Edwards, C.A. Interactions between Eisenia andrei (Oligochaeta) and nematode populations during vermicomposting. Pedobiologia 2003, 47, 53-60. [CrossRef]

36. Timper, P.; Davies, K.G. Biotic interactions. In Nematode Behaviour; Gaugler, R., Bilgrami, A.L., Eds.; CAPI Publishing: Wallingford, UK, 2004; pp. 277-307. 